\title{
Exploring The Role Of Phronesis In Social Innovation: A Case Study Of Dr. Ruth Pfau
}

\author{
Ansar Waseem \\ \& \\ Yasir Rashid \\ School of Business \& Economics \\ University of Management \& Technology, Lahore
}

\begin{abstract}
Although recent literature on social innovation proclaims its virtue in addressing unmet social needs. Yet little is known about the relationship between phronesis and social innovation. This paper aims to explore how a social entrepreneur uses phronesis in addressing a social problem. Taking case study as qualitative research inquiry, this paper uses the interviews and life account of Dr. Ruth Pfau (Late) on how she incorporated her phronesis in treating patients suffering from leprosy. The empirical evidences collected were analyzed using GIOIA data analysis. The results of the data analysis show that a social entrepreneur employs his/her practical wisdom, experiential knowledge, and value judgment in combating a social issue, and in doing so, uses phronesis in addressing a social problems and creating social innovation.
\end{abstract}

Keywords: Phronesis; Practical Wisdom; Value Judgement; Social Innovation.

$$
\begin{aligned}
& \text { تلخيص }
\end{aligned}
$$

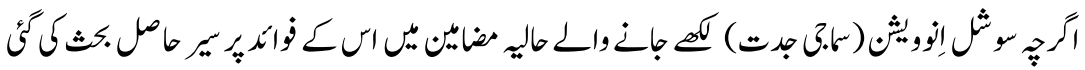

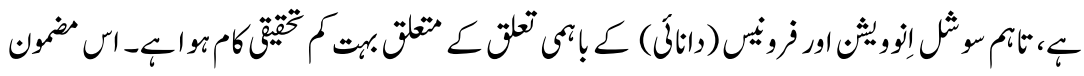

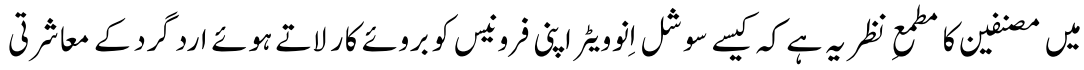

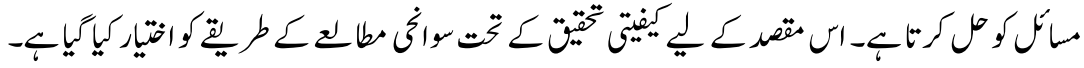

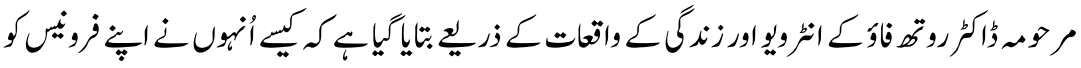

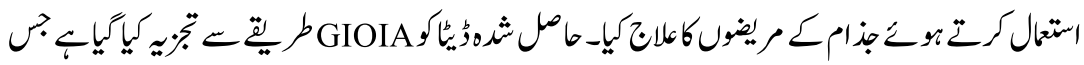

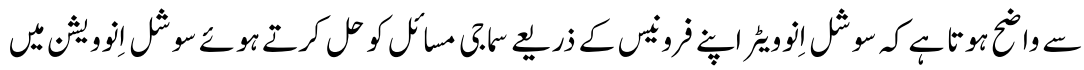

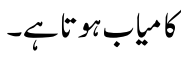

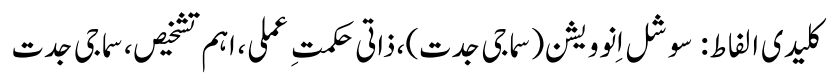




\section{Introduction}

Social innovation is a remedy to deal with the 'wicked problems' (Desouza \& Smith, 2014) faced by deprived section of community. These are extra ordinary initiatives taken by seemingly ordinary people to tackle the problem faced by them or their fellows (Baker \& Mehmood, 2015). Social innovation is the process of designing and implementation new and creative ways to solve a social problem or fulfilling some previously unmet social need(s). It attempts to achieve workable new ideas and approach which help in achieving social goals or addressing a social challenge in a new way (Lyon, 2012; Manzini, 2014). According to Bulut, Eren, \& Halac (2013) social innovation has three characteristics. First, the innovation is created to meet a social need. Second this innovation should produce a change in society, and third it should be readily acceptable for all stakeholders. Social innovation is the journey towards a better world (Reinstaller, 2013).

Phronesis of social innovator may prove to be beneficial in ensuring social inclusion of the special children. Aristotle coined the term phronesis in his book Nicomachean Ethics which is regarded as a comprehensive work in the role of ethics during human action (Noel, 1999). Phronesis is described as "wise practical reasoning" (Eisner, 2002). However, what set phronesis apart from other forms of knowledge are its emphasis values and ethics. Phronesis emphasizes on the action which ought to be an "ethically practical action" (Grint, 2007). It is believed to be the ability to take action rather than being just a body of knowledge. Thus it can be considered as an experiential knowledge. Phronesis appreciates the sensitivity of context, and deals with application of value judgment in particular situation at hand.

There are a number of social problems which are prevalent in under developed countries. Unfortunately, governments of these do little work in combating these issues. Accordingly, the private sector has to step forward and fill this void. Being an action oriented field, social innovation can benefit from the application of phronesis and value judgment of social entrepreneurs. These social entrepreneurs are motivated by their value judgment and their propensity for common good. However, literature is silent about regarding the role of phronesis in social innovation. Less is known how a social innovator employs his value judgment and experiential knowledge in bringing about a social innovation. This leads to an important yet unattended question in research becomes: How social innovator uses experiential knowledge and value judgment in social innovation initiative? And in doing so, how phronesis can be helpful in addressing a social problems and creating social innovation? 
The objective of this study is twofold: To explore the role of phronesis of social entrepreneur in social innovation, and how these knowledgeable agents applies their practical knowledge and value judgment in combating a social problem? For this, a qualitative research inquiry using case study methodology is used. To study social innovation in Pakistan, there is no better person than Late Dr. Ruth Pfau. Known as Mother Teresa of Pakistan, she was instrumental in bringing down leprosy to a controlled level. The data is collected through interviews conducted by different people with Dr. Ruth Pfau which are readily available on internet. The data collected through the interview is analyzed using the GIOIA data analysis which complements ground theory methodology. This type of data analysis is helpful in determining first and second order themes which are then distilled into aggregated themes using an inductive approach.

Researchers, practitioners and governments started to take interest in social innovation during 1990s because of weak global and domestic economy (de Bruin \& Shaw, 2013). Despite being a buzz word, umbrella term or container concept, the field of social innovation is generally underexplored and a great deal of work can be done in this field (Chalmers, 2013; Phillips et al, 2015; Reinstaller, 2013). This research strengthens the literature on social innovation by providing evidence that it is "more than a discursive fad" (Sinclair \& Baglion, 2014, p. 470). Majority of studies claims that social innovation spreads in a society through social enterprises. As such the extant literature focuses on the role of for-profit and non-profit organizations in diffusion of social innovation, an important premises is often missed i.e. what motivates social innovator in satisfying social need. Secondly, the specific traits of social innovators are often neglected i.e. what prompts these people to engage in social activities. This study proposes that the value judgment and ethical consideration of these people urges these people to concentrate on social issue in lieu of traditional economic activities.

\section{Literature Review}

\section{Social Innovation: Tackling Social Problems}

Social innovations are ventures developed by those organizations whose primary purpose is social, and they come up with innovative ideas to meet a social need. Similar to technical innovation, social innovation are conceived by an individual or a group of individuals when they confront a social problem and realize a dire need to find innovative solutions for it (Westley et al, 2014). However contrary to technical innovation, social innovation desires to produce long term outcomes that are important for the entire society (Bekkers, Tummers \& Voorberg, 2013). Therefore, social innovation has emerged as a mean to produce change in the 
society, and transform "basic routines, resource and authority flows and beliefs of any social system" (Westley \& Antadze, 2010, p. 2) to meet some social goals.

Social innovation became popular among social scientists, researchers, practitioners and governments in 1990s (Sinclair \& Baglion, 2014). Since then, social innovation programs are on the rise and are expected to grow because of the on-going economic crises, budget constraint, economic stagnation, austerities, and lesser spending of the government on social welfare projects. Moreover, prolong periods of recession has severely hit the profit of corporate enterprise limiting corporate philanthropy. In some countries, this has created divide, exclusion, and inequality in the society. There is growing concern that the old practices to address these problems have failed miserably (Urama \& Acheampong, 2013). The need for social innovation has risen from people's suffering in the deprived areas, unemployment, closure of factories, and lack of government support (Baker \& Mehmood, 2015). Now society as a whole is engaging in social innovation to deal with social and economic challenges in order to make real changes in people's life. At micro level, social innovation is aimed at improving standard of living, quality of life, and enhancing capabilities of individuals; while at macro level it attempts to change social norms and culture to combat inequality and injustice; thereby producing a sustainable development.

Social enterprise, social innovation and social entrepreneurship lie at the extreme end of private sector continuum (Phillips et al, 2015). The locus of social innovation has changed considerably over the last decade. Instead of relying on state-sponsored ventures to answer social problems, social innovation programs developed by the civil society are now gaining prominence (Chalmers, 2013). A number of stakeholders are involved in the process of social innovation but the most pertinent ones include social activists or third sector, and Schumpeterian social entrepreneurs (Edwards-Schachter, Matti, \& Alcantara, 2012). Individuals have become torch bearers of driving social change by establishing social enterprises that blend social and commercial purpose of the organization. Thus, "the concept of social innovation pays attention to the individual embedded in social groups and focuses on the collective responses to social problems as a way to reinforce these capabilities" (Miquel, Cabeza \& Anglada, 2013, p. 156).

Social innovation is an umbrella term and a number of different approaches come under its purview. A number of concepts such as social entrepreneurship, social innovation, third sector organizations, community initiative, social movement, social economy, come under the umbrella term of social innovation (CajaibaSantana, 2014; Sinclair \& Baglion, 2014). The concepts of social innovation has been explored from different domains of social sciences such as sociology, 
management, business administration, public policy, political sciences, social entrepreneurship, urban and regional development, and human development economics (Ruede \& Lurtz, 2012). For example, Pol and Ville (2009) have conceptualizes the literature social innovation in four overlapping approaches. In the first approach, the social innovation is identical with institutional change as it tries to modify the cultural, normative and regulatory structure of these public institutions. The second conceptualization concentrates on improving the quality and quantity of life through social innovation. The third strand emphasizes on public welfare and good while the last one entails the role of social innovation in satisfying those social needs which are neglected by civic organizations and market.

\section{Phronesis: The Revival of Aristotle's Moral Judgment}

Aristotle in his seminal work Nicomachean Ethics coined the term phronesis. Nonaka \& Toyama (2007) define phronesis as "the ability to determine and undertake the best action in a specific situation to serve the common good". Since, there is no direct translation of the work Phronesis in English, therefore, different authors have used terms to explain phronesis. Noel (1999) uses terms such as practical reasoning, moral insight, and moral discernment to explain phronesis, along with a range of interpretations for phronesis like 'state of capacity' and 'characteristic of a person'. Grint (2007) declare phronesis as moral knowledge whereas Saugstad (2005) considers it as practical knowledge. Nonaka and Holden (2007) closely equates phronesis with prudence and practical wisdom, while Halverson (2004) considers it as 'experiential knowledge'. Breier and Ralphs (2009) have complemented these descriptions with terms like practical judgment and intelligence.

Phronesis is generally regarded as moral form of knowledge which stems from virtues of character. As Aristotle (1999) describes it "The agent also must be in a certain condition when he does them; in the first place he must have knowledge, secondly he must choose the acts, and choose them for their own sakes, and thirdly his action must proceed from a firm and unchangeable character."

Therefore, ability to make moral judgment about the common goodness is the core characteristics of phronesis (Nonaka \& Toyama, 2007). Moral component of phronesis focuses on the pursuing good quality life by taking into consideration wider good for community (Breier \& Ralphs, 2009). It is a conscious attempt to reach Eudaimonia (happiness) by focusing on the greater cause. It calls for virtues of character and thoughts, rising beyond personal interest and do task which is good for all (Grint, 2007). Gallagher (2007) holds the view that a person having the moral agency possesses the capacity of phronesis. 
Phronesis is action oriented (Flyvbjerg, 2004; Grint, 2007; Surprenant, 2012) based on the character of a person, experiential knowledge and practical wisdom. Phronesis is high level of tacit knowledge which enables a person to make practical decision based on the moral and ethical values (Nonaka \& Toyama, 2007). It is basically exercise of skills which cannot be fully described. It deals with the practical rationality and judgment of a person which is in turn related with experience in a particular domain. For this reason, phronesis cannot be taught (Breier \& Ralphs, 2009) since there is no formula to learn moral judgment and prudence (Grint, 2007). Wisdom is only be learned through experience and a person becomes wise when he passes through difficult and vague situations (Schwartz \& Sharpe, 2006).

Phronesis, just like expertise and wisdom, is a highly context dependent as oppose to episteme which is context free (Grint, 2007). Phronesis pertains with the particulars (Aristotle, 1999). Gallagher (2007) believes that the target of phronesis is the person itself, who works as a moral practitioner in very particular situation. Instead of developing overarching principles or rules and procedures; phronesis deals with the ability to adjust knowledge of the possessor to particular situation (Halverson, 2004). Phronesis insists that expertise should be used within a particular context for collective good. This means that the moral knowledge should be adjusted to the particular demands of the situation at hand. It is imperative for a phronetic practitioner (the one who is excising phronesis) that he must understand the unique characteristics of the situation in which she is operating. This calls for 'emotional attunement' and 'spontaneous action' to adjust with the idyonsncracy of the situation (Shotter \& Tsoukas, 2014).

\section{Research Design}

Identifying and using a suitable research methodology is essential for execution of a successful research (Cho \& Lee, 2014). However, the choice of research methodology is contingent upon the researcher's belief about nature of reality. In this study, we are assuming a relativist stance. We are refuting the existence of an objective reality. Rather we are taking subjectivist epistemological position believing that there can be multiple realities which are social constructed and vary with person to person (Mills, Bonner, \& Francis, 2006). For the purpose of this study, our focus is on social innovation, which is ontologically and epistemologically different from technical innovation. As social innovation is a social process, the breadth and width of the concept cannot be captured by statistical techniques (de Bruin \& Shaw, 2013). In addition, phronesis is also lived experienced of the individual. Hence, it is hard to measure phronesis in term of quantitative research and positivist paradigm. 
There are different research approaches available within qualitative paradigm, but this study employs case study methodology. A case study "investigates a contemporary phenomenon within its real-life context; when the boundaries between the phenomenon and context are not clearly evident; and in which multiple sources of evidence are used" (Yin, 1989, p. 23). The term case in a case study involves an individual, an entity, an organization, a feature or even a unit of analysis (Noor, 2008). Case study pertains with the study of practice that makes it easier to study phenomena such as social innovation and phronesis. Moreover, case study yields context bound knowledge which makes it suitable for studying phronesis as the latter is also highly context dependent As stated above, Dr Ruth Pfau and her achievement in bringing leprosy in Pakistan to a controlled level is the case for this study. As Dr Ruth Pfau passed away on $10^{\text {th }}$ August 2017, it is not possible to conduct an interview with her. But, her interviews conducted by different people are readily available on internet. For this study, we are using these interviews to collect empirical evidence.

\section{Data Analysis}

The data collected was analyzed through GIOIA data analysis developed by Denis A. Gioia and colleagues. This method provides an impression of qualitative rigour to the readers by representing results with the help of visual aids (Gioia, Corley \& Hamilton, 2013). Data analysis starts with first order analysis by staying faithful with the terms used by the informants. Different interviews of Dr. Ruth Pfau available on internet were analysed to find different first order categories. These were then labelled by using the words and phrases of the informant.

Then the researcher, being a knowledgeable agent, analysed the statements of informants in the light of the contextual factors and theoretical concepts to distil first order categories into second order themes. The interviews were listened again and again to achieve better understanding. Due to this analysis, different second order themes are generated. As compared to first order categories, the second themes are at higher level of abstraction. These second order categories are possible answer to our research questions. From these second order themes aggregated dimensions were driven inductively (Nag \&Gioia, 2012) which correspondence with both the major concepts in the study.

All these findings are presented with the help of visual aid termed as data structure (Gioia, Corley, \& Hamilton, 2013). This makes it easier to understand how findings have been obtained from the data. Figure No 1 shows the results of the data analysis. 
Figure No 1: Data Structure

First Order

Categories

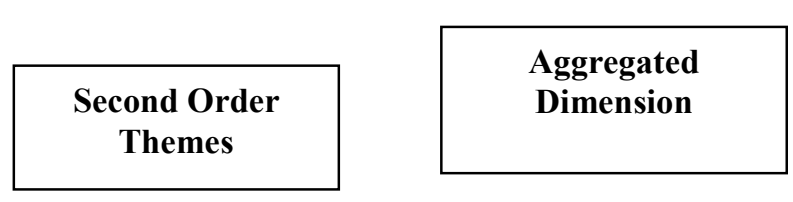

- Early death of brother encouraged me to become a doctor [so that other may be prevented].

- After visiting leper colony decided that I can't leave these people.

- they (patient) have such as miserable life at least I can't sit back and watch it.

- Didn't marry because you cannot be on two boats at the same time

- Decided not to have kids because they won't let me do public service.

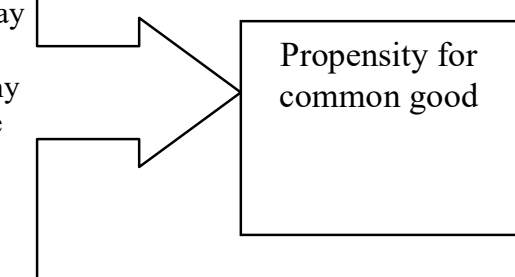


- Till 1960, people of Pakistan were unaware that leprosy is curable.

- In 1960, there was no single doctor for leprosy.

- Only one Mexican pharmacist was working for leprosy patients.

- Started from a hut as it was impossible at that time to establish a hospital.

- The hut was later upgraded into Marie Adelaide Leprosy Center.

- There are now 157 centers working all over Pakistan. You name the place; you will find our center there

- Later developed treatment centers for tuberculosis for Northern Areas and Azad Kashmir as well as blinded prevention in Balochistan.

- Another NGO with the name Raah-e-Nijat for helping the oppressed Hindu community of rural Sindh.

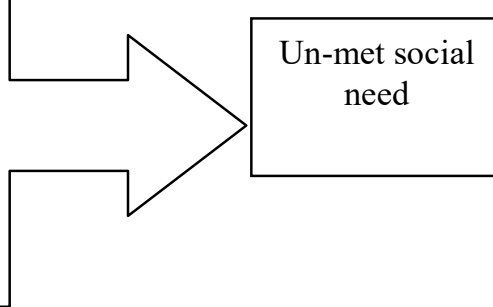


contains the explanation of the two aggregated dimensions that are revealed by data analysis.

\section{Phronesis}

This aggregated dimension contains second order themes which different researchers have used to describe phronesis. These include: Propensity for common good, value judgment, experiential knowledge and practical wisdom.

Propensity for common good: The journey to become a social innovator starts with a motivation. In case of Dr. Ruth Pfau it started from a personal tragedy. She explains that

"It was Second World War, and I was young at that time ... We were five sisters and one brother. My brother died at the age of 9 due to war. He was suffering from pneumonia and curfew was imposed at night in our city. My father run to call a doctor, but the doctor didn't consider it worthwhile to risk his life for someone else. Eventually my brother died in the morning due to no medical treatment. That day I decided to become a doctor."

It was this personal tragedy which encouraged Dr. Ruth Pfau to become a physician. Later, under the influence of her spiritual calling she joined Sisters of the Immaculate Heart of Mary. Under activities of this mission, she initially intended to go to India. But, due to certain visa issues she had to stay in Karachi, Pakistan, and here her life changed.

"My fellow sister (nun) took me to leper colony in McLeod Road (Karachi) ... I saw the patients who were barely resemble human. After visiting the leprosy colony once, I realized that I can't leave this place. If I left, I won't be able to sleep and I will always have this pain in my heart. Who will look after these people?"

It was under the influence of these factors, Dr Ruth Pfau took the decision to become a physician and help the leprosy patients. It was her propensity for common good that encouraged her to take these difficult decisions, and she devoted herself to help people suffering from a serious ailment.

Value Judgment: Her decision to stay in Karachi and help the leprosy patients gives a clue about her value judgment. She could have used her education for better earning or career prospects. But, she gave more importance to moral values than her personal benefits. She made helping these people mission of her life as she was convinced it was her destiny.

"My first motivation really came off as human being like me and you. People have only one life to live and then it's over. . If they 
(patient) have such as miserable life at least I can't sit back and watch it."

She even did not give attention to her personal life. Her decision to become a nun and devote her life for public service was guided by her value judgment that God has created her for this purpose. As she narrates:

"I had two romantic relationships in Germany. . . . But you cannot do or get everything in your life. But it was my decision ... You cannot be on two boats at the same time."

At one point she further illustrates her point

"I also decided at a very young age that I won't marry because I thought if I would marry and have kids, my kids won't let me go to public service. It would be difficult for me . . A Although, I let go of this happiness but I got other happiness (by helping others) and peace of heart."

Experiential Knowledge \& Practical Wisdom: An important facet of phronesis is the use of experiential knowledge and practical wisdom of the person to achieve common good. Past experiences encourage a person to strive to make present better than past. A person experiencing a particular misery in past is better aware about the pain and agony of others.

"The conditions in the McLeod road were sub human. I mean I have seen much misery during the war because I am a war generation. But, I didn't see misery without a hope which I saw in McLeod Road."

When Dr Ruth Pfau reached Pakistan, there was no doctor who specialized for leprosy treatment. Even her own background and education is not related with it. During her formal education, she didn't receive any education related to this particular ailment. But, she was determined to help others so she started by educating herself about it. She consulted literature to study how leprosy developed and how it can be cured. She even enlisted help of others so she may become more equipped in treating people. She narrates her journey as under.

"I am a gynecologist, and I knew nothing about leprosy. When I saw there is no chance (of learning) in Pakistan. . . . I searched in Karachi for any doctor having specialization of leprosy. So, I started by reading a book on leprosy treatment. Since, I was a doctor I had basic know how. After that, I went to Madras (India). Madras had higher rate of leprosy patient, so the doctors there had more experience about it. I remained there for few weeks, learned treatment there and came back to Pakistan." 
This is how she applied her practical knowledge in helping others. She didn't stop at this. Rather, she constantly upgraded her knowledge base and learned of new treatments for leprosy. As she explains herself:

"Even now, I have learned and tested new treatment which previously made it difficult for the patients to have a profession."

\section{Social Innovation}

Dr Ruth Pfau used different facets of phronesis to heal people. She not only spotted an unmet social need but also applied an innovative solution to deal with this. She didn't stop at this. Rather, she ensured that her initiatives become sustainable and lasting, and these will grow to have a positive influence on the life of others.

Unmet Social Need: Dr. Ruth Pfau employed her phronesis to help deprived section of community. She was able to feel the misery of people which others ignored. When she came to Pakistan in 1960, there was no institution or treatment facility for leprosy patient and it was assumed to be an incurable disease. People were ignored about any potential treatment or cure for these patients. As Dr Ruth Pfau commented in one of her interviews:

"There was a treatment for leprosy since 1942. But, we in Pakistan didn't know it. It was only in 1960 people came to know that it is a disease which is curable. It is a normal disease".

Such was the condition at that time that there was no doctor who treated for these patients. As a result, these people were either confined to a leper colony or restricted to McLeod road were they used to lay on road sides in mutilated conditions. As Dr Ruth Pfau narrates:

"In 1960, there was no single doctor for leprosy. One of my sisters took me to the McLeod Road. This was a Mexican pharmacist who came just before I came, and she was instrumental in get me to Pakistan. Because she kept on writing I need a doctor, I need a doctor. I need a doctor. I had just completed my studies and it was a challenge which I thought was worthwhile".

Innovative Solution: Dr. Ruth Pfau was so moved with the agony of these people that she decided to help them. She with the help of other people of her mission managed to build a makeshift arrangement to treat leprosy patients. She didn't wait for government support. Rather, she decided to work on her own and started from a humble beginning. She recalls those days by stating:

"Before me, our fellow sister started treatment of leprosy patient. We started from a hut as it was impossible at that time to establish a hospital. (Leprosy treatment) started all of a sudden. We didn't have the time to think. We have to get medicine and start treatment." 
With the passage of time, her efforts began to materialize. People around the country started to visit her facility for treatment of leprosy. She emerged as a beacon of light for these people. Patients from far flung areas even Afghanistan visited Dr Ruth Pfau for treatment. Her efforts were acknowledged by government of Pakistan as well as donor agencies of Germany. This led her to found Marie Adelaide Leprosy Centre which became a sign of life for underprivileged people:

"The hut was later upgraded into Marie Adelaide Leprosy Center.

We established relationship with people. Local governments and doctors helped us. But the majority of funds came from Germany."

Sustainable initiative: Dr. Ruth Pfau and her team didn't stop at this. They expanded their operation and established leprosy treatment centres throughout Pakistan. Government of Pakistan supported them and provided them with requisite resources for expansion their operation. CEO of Marie Adelaide Leprosy Center shares this achievement as:

"The out-reach program for leprosy treatment started with the help of federal and provisional governments. Government helped us and offered their facilities to us. We hired and trained staff, and government absorbed it. These people were deputed in basic health unit. There are now 157 centers working all over Pakistan. You name the place; you will find our center there." (CEO of Marie Adelaide Leprosy Center)

Due to this strenuous efforts and stoic determination, Dr Ruth Pfau was able to control leprosy in Pakistan. In 1996, World Health Organization declared Pakistan to the first Asian country which has brought leprosy to a controlled level. However, but for Dr Ruth Pfau this was not the end of journey. With leprosy under controlled, she turned her attention to other social problems prevalent in Pakistan and employed her experience and base of operation for helping other deprived communities of country:

"Once we managed to bring leprosy to a controlled level, we have later developed treatment centers for tuberculosis for Northern Areas and Azad Kashmir as well as blinded prevention in Balochistan."

She didn't remain restricted to health sector. Rather, she used her reputation to help oppressed segment of community. She states that

"Another NGO with the name Raah-e-Nijat is working to help the oppressed Hindu community of rural Sindh."

Positive Influence on People: All these activities had a positive influence on other life. An important silent revolution which Dr Ruth Pfau brought was the change in the perception of people. Initially, Leprosy was considered to be incurable. Patients 
of leprosy were considered to be cast out and other people hesitate to interact with them. These patients were forced to spend their life in sub human conditions, and they had no respectable occupation or normal life. Her activities and efforts brought a positive change among people. She narrates another story.

"The people once sufferings from leprosy once cure are rehabilitated. They go back to work. On my way to church a young man stopped me and asked: you don't know me. I said: I am sorry; you tell me your name. He said: I am son of one of the beggars (leprosy patient) of McLeod Road, and I have just passed my BA."

\section{Discussion on Findings}

Aristotle was the first person to advocate the virtues of phronesis. However, it was not until recently scholars have started to emphasize on the role of moral practices and value judgment in organizational routine. By the end of last century, social innovation has become a buzz words among researchers, and this concept has been applied to different fields. This study aims to combine these two concepts and suggest how a social entrepreneur employs his/her phronesis to produce social innovation. For this purpose, we have chosen Dr Ruth Pfau as our case study as she exhibited different aspects of phronesis and social innovation. From her life accounts, it is evident that she was driven to become a social innovator under the influence of her moral judgment and ethical consideration. Furthermore, her phronesis was instrumental in developing programs to combat social challenges, and creating an inclusive environment for special people.

Many definitions concentrate on the impact of social innovation, and encourage the social entrepreneur to give preference to collective benefits. Social innovation benefits from the value judgment of social entrepreneurs. According to Breier \& Ralph (2009) "phronesis is said to have a moral or ethical component, to be geared towards the achievement of a good life, in a manner that takes account of a wider community, and to be acquired with experience." After completing her education, Dr Ruth Pfau could have become a professional doctor and earn a handsome living like majority of counterparts. But, she rose above her personal interests and valued common good. Herphronesis encouraged her to find out solution which serves the common good. Her value judgment made her capable in dealing with a social problem by utilizing her resources voluntarily.

Social innovation is much more than a theoretical field. It is "wisdom of practice" (Sinclair \& Baglion, 2014). Therefore, it requires practical wisdom and experiential knowledge of the entrepreneurs. As succinctly described by Hawkins (1966) "[these are such] times in human history when there is much more wisdom in practice than in the academy, when gamblers know more about probability than statisticians, and when sailors know more about the heavens than astronomers" (p. 3). Phronesis and value judgment of Dr. Ruth Pfau drove her to become a social 
entrepreneur. Instead of discussing the issue in private gathering, she jumped into the practical field and tackled a social issue head on. Dr. Ruth Pfau employed her experiential knowledge to help a neglected sector of community.

As with any technical innovation, social innovation requires domain related expertise of the entrepreneurs to come up with new answers to social challenges. In her battle against leprosy, Dr Ruth Pfau realized that she should have practical knowledge against this disease. For this purpose, she went to India to learn more about treatment for leprosy. She constantly upgraded her knowledge base and equipped herself with new treatments of leprosy. The skill and domain related knowledge of Dr Ruth Pfau helped her to solve social problem.

\section{Conclusions}

Lately, scholars have displayed profound interest in phronesis. Furthermore, social innovation is asserting its dominance and replacing corporate social responsibility. By combining these two different concepts, this study aims to provide evidence on how phronesis of a person can be used for the purpose of social innovation. By doing so, it is revealed that these two are not just theoretical concepts. Rather, they hold practical relevance. This has been proved by the life account and achievements of Dr Ruth Pfau who has used her inclination for common good, value judgment, experiential knowledge, and practical wisdom to combat and defeat a social issue which was previously ignored by government and private sector alike. By doing so, she has left behind her a legacy which can guide others to follow. As Dr Ruth Pfaudescribe succinctly: "Not all of us can prevent a war; but most of us can help ease sufferings - of the body and the soul."

\section{References}

Aristotle (1999). Nicomachean Ethics. Kitchner: Batoche Books.

Baker, S. \& Mehmood, A. (2015). Social Innovation and the Governance of Sustainable Places. Local Environment: The International Journal of Justice and Sustainability, vol.20:3, pp.321-334.

Bekkers, V., Tummers, L. G. \& Voorberg, W. H. (2013). From Public Innovation to Social Innovation in the Public Sector: A Literature Review of Relevant Drivers and Barriers. Rotterdam: Erasmus University Rotterdam.

Breier, M. \& Ralphs, A. (2009). In Search of Phronesis: Recognizing Practical Wisdom in the Recognition (Assessment) of Prior Learning. British Journal of Sociology of Education, vol.30:4, pp.479-493. 
Bulut, C., Eren, H. \& Halac, D. S. (2013). Social Innovation and Psychometric Analysis. Procedia-Social and Behavioral Sciences, vol.82, pp.122-130.

Cajaiba-Santana, G. (2014). Social Innovation: Moving the Field Forward. A Conceptual Framework. Technological Forecasting and Social Change, vol.82, pp.42-51.

Chalmers, D. (2013). Social Innovation: An Exploration of the Barriers Faced by Innovating Organizations in the Social Economy. Local Economy, vol.28:1, pp.17-34.

De Bruin, A. \& Shaw, E. (2013). Social Innovation and Social Entrepreneurship: Extending Theory, Integrating Practice. International Small Business Journal, vol.29:1, pp.737-746.

Desouza, K. C. \& Smith, K. L. (2014). Big Data for Social Innovation. Stanford Social Innovation Review, pp.39-43.

Edwards-Schachter, M. E., Matti, C. E. \& Alcantara, E. (2012). Fostering Quality of Life through Social Innovation: A Living Lab Methodology Study Case. Review of Policy Research, vol.29:6, pp.672-692.

Eisner, E. W. (2002). From Episteme to Phronesis to Artistry in the Study and Improvement of Teaching. Teaching and Teacher Education, vol.18:4, pp.375-385.

Flyvbjerg, B. (2004). Phronetic Planning Research: Theoretical and Methodological Reflections. Planning Theory \& Practice, vol.5:3, pp.283-306.

Gallagher, S. (2007). Moral Agency, Self-Consciousness and Practical Wisdom. Journal of Consciousness Studies, vol.14:5-6, pp.199-223.

Gioia, D. A., Corley, K. G. \& Hamilton, A. L. (2013). Seeking Qualitative Rigor in Inductive Research: Notes on the Gioia Methodology. Organizational Research Methods, vol.16:1, pp.15-31.

Grint, K. (2007). Learning to Lead: Can Aristotle Help us Find the Road to Wisdom? Leadership, vol.3:2, pp.231-246.

Halverson, R. (2004). Accessing, Documenting, and Communicating Practical Wisdom: The Phronesis of School Leadership Practice. American Journal of Education, vol.111:1, pp.90-121. 
Hawkins, D. (1966). Learning the Unteachable. In L. S. Schulman \& E. R. Keislar (Eds.), Learning by Discovery: A Critical Appraisal. Chicago: Rand McNally.

Lyon, F. (2012). Social Innovation, Co-Operation and Competition: InterOrganizational Relations for Social Enterprises in the Delivery of Public Services. In A. Nicholls \& A. Murdock (Eds.), Social Innovation (pp. 139-161): Palgrave MacMillan.

Manzini, E. (2014). Making things Happen: Social Innovation and Design. Design Issues, vol.30:1, pp.57-66.

Miquel, M. P., Cabeza, M. G. \& Anglada, S. E. (2013). Theorizing Multi-Level Governance in Social Innovation Dynamics. In F. Moulaert, D. MacCallum, A. Mehmood, \& A. Hamdouch (Eds.), The International Handbook on Social Innovation: Collective Action, Social Learning and Transdisciplinary Research (pp. 155-168).

Nag, R. \& Gioia, D. A. (2012). From Common to Uncommon Knowledge: Foundations of Firm-Specific Use of Knowledge as a Resource. Academy of Management Journal, vol.55:2, pp.421-457.

Noel, J. (1999). On the Varieties of Phronesis. Educational Philosophy and Theory, vol.31:3, pp.273-289.

Noor, K. B. M. (2008). Case Study: A Strategic Research Methodology. American Journal of Applied Sciences, vol.5:11, pp.1602-1604.

Nonaka, I. \& Holden, N. (2007). A Made-in-Japan Theory with Help from Aristotle: Nigel Holden Interviews Ikujiro Nonaka. European Journal of International Management, vol.1:1-2, pp.104-110.

Nonaka, I. \& Toyama, R. (2007). Strategic Management as Distributed Practical Wisdom (phronesis). Industrial and Corporate Change, vol.16:3, pp.371-394.

Phillips, W., Lee, H., Ghobadian, A., O’Regan, N. \& James, P. (2015). Social Innovation and Social Entrepreneurship: A Systematic Review. Group \& Organization Management, vol.40:3, pp.428-461.

Pol, E. \& Ville, S. (2009). Social Innovation: Buzz word or Enduring Term? The Journal of Socio-Economics, vol.38:6, pp.878-885. 
Reinstaller, A. (2013). An Evolutionary View on Social Innovation and the Process of Economic Change. WWWforEurope Working Paper, No. 43.

Ruede, D. \& Lurtz, K. (2012). Mapping the Various Meanings of Social Innovation: Towards a Differentiated Understanding of an Emerging Concept. EBS Business School Research Paper Series 12-03.

Saugstad, T. (2005). Aristotle's Contribution to Scholastic and Non-Scholastic Learning Theories. Pedagogy, Culture \& Society, vol.13:3, pp.347-366.

Schwartz, B. \& Sharpe, K. E. (2006). Practical Wisdom: Aristotle Meets Positive Psychology. Journal of Happiness Studies, vol.7:3, pp.377-395.

Shotter, J. \& Tsoukas, H. (2014). In Search of Phronesis: Leadership and the Art of Judgment. Academy of Management Learning \& Education, vol.13:2, pp.224-243.

Sinclair, S. \& Baglioni, S. (2014). Social Innovation and Social Policy-Promises and Risks. Social Policy and Society, vol.13:3, pp.469-476.

Surprenant, C. W. (2012). Politics and Practical Wisdom: Rethinking Aristotle's Account of Phronesis. Topoi, vol.31:2, pp.221-227.

Urama, K. C. \& Acheampong, E. (2013). Social Innovation Creates Prosperous Societies. Stanford Social Innovation Review, vol.11:3, pp.9-11.

Westley, F. \& Antadze, N. (2010). Making a Difference: Strategies for Scaling Social Innovation for Greater Impact. Innovation Journal, vol.15:2.

Westley, F., Antadze, N., Riddell, D. J., Robinson, K. \& Geobey, S. (2014). Five Configurations for Scaling up Social Innovation: Case Examples of Nonprofit Organizations from Canada. The Journal of Applied Behavioral Science, vol.50:3, pp.234-260.

Yin, R. K. (1989). Case Study Research: Design and Methods. Beverly Hills, CA: Sage Publications.

Ansar Waseem is Ph.D Scholar in the School of Business \& Economics, University of Management \& Technology, Lahore.

Dr. Yasir Rashid is an Assistant Professor in the School of Business \& Economics, University of Management \& Technology, Lahore. 